\title{
PEREKAYASAAN AKUNTANSI ISTISHNA’ PADA PRODUK PEMBIAYAAN APARTEMEN
}

\author{
(STUDI KASUS: BANK SYARIAH X) \\ Erina Maulidha dan Asrul Aminulloh \\ Program Studi Akuntansi Syariah \\ Sekolah Tinggi Ekonomi Islam SEBI \\ Email: erina_born@yahoo.co.id
}

\begin{abstract}
Adoption of PSAK 104 on Accounting Istishna, creating an obstacle for Islamic banks. Plus the difficulty of implementing the contract istishna itself in the banking business. PSAK related more appropriately applied to the real sector companies engaged instead of banking services. This study aims to determine the constraints and associated engineering analysis accounting istishna 'apartment on financial products in Islamic banks. The research method used is descriptive qualitative field research. Analysis was used to compare the conditions obtained in the field by the recognition of regulated accounting under PSAK 104 and the legislation in force. Based on the analysis, there are several obstacles that arise in the application of financing istishna, which is related to information technology, human resources and the prevalence of apartment construction business in Indonesia in the implementation of accounting standards. Consequently, in practice, Islamic banks have not fully adopted PSAK 104, especially in terms of disbursement of funds to the developer, the recognition of revenue on accrual basis and cash basis, and margin recognition in installments during construction by the customer.
\end{abstract}

Kata Kunci: accounting istishna', apartment financing, Islamic bank

\section{PENDAHULUAN}

Perbankan syariah mulai diperkenalkan mulai tahun 1992 yang diawali dengan munculnya Undang-Undang No.7 tahun 1992 tentang perbankan. Selanjutnya, muncul Undang-Undang No. 10 tahun 1998 terkait perubahan UU No. 7 tahun 1992. Kemudian, muncul peraturan terbaru terkait bank syariah yang diatur dalam UU No. 21 tahun 2008. Perubahan ini merupakan peluang besar bagi bank syariah untuk lebih memperluas perannya sebagai pihak intermediasi antara surplus dana dengan defisit dana.

Perbankan syariah di Indonesia saat ini mengalami kenaikan aset yang signifikan. Menurut data statistik perbankan Indonesia, pada bulan Mei 2011, aset perbankan syariah naik sebesar 706 miliar dari bulan sebelumnya. Sedangkan pada bulan Juni 2011, aset perbankan syariah naik sebesar Rp 1.623 miliar dari bulan sebelumnya. Data perkembangan aset bank syariah ditunjukkan dalam tabel 1.1 dan grafik 1.1. 
Tabel 1. 1 Perkembangan Aset Bank Syariah tahun 2011

\begin{tabular}{|c|c|c|c|c|c|c|}
\hline & Jan & f'eb & Mar & Apr & Mei & Iun \\
\hline BUS & 78.203 & 78.126 & 83.198 & 81.981 & 85.040 & 88.834 \\
\hline ITIS & 17.540 & 17.861 & 17.991 & 18.587 & 19.293 & 20.916 \\
\hline
\end{tabular}

Kenaikan perkembangan aset baik pada Bank Umum Syariah (BUS) maupun Unit Usaha Syariah (UUS) dapat dilihat pada grafik 1.1

Grafik 1. 1 Perkembangan Aset Bank Syari'ah Tahun 2011

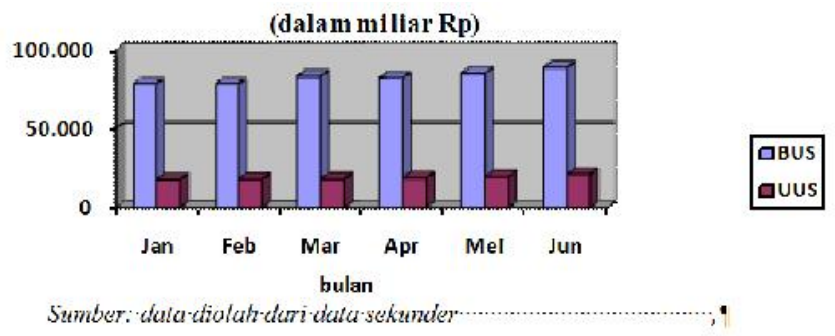

Menurut Karim (2010), pada dasarnya, produk yang ditawarkan oleh perbankan syariah dapat dibagi menjadi tiga bagian besar, yaitu produk penyaluran dana, penghimpunan dana, dan jasa. Terkait mekanisme kerja bank syariah disebutkan oleh Ascarya (2007), bahwa bank syariah melakukan kegiatan pengumpulan dana dari nasabah melalui deposito, investasi maupun titipan giro dan tabungan. Dana yag terkumpul kemudian diinvestasikan pada dunia usaha melalui investasi sendiri (nonbagi hasil/trade financing) dan investasi dengan pihak lain (bagi hasil/investment financing). Ketika ada hasil (keuntungan), maka bagian keuntungan untuk bank dibagi kembali antara bank dan nasabah pendanaan. Di samping itu, bank syariah dapat memberikan berbagai jasa perbankan kepada nasabahnya.

Dalam menyalurkan dananya pada nasabah, Karim (2010) menyebutkan bahwa secara garis besar produk pembiayaan terbagi ke dalam empat kategori yang dibedakan berdasarkan tujuan penggunaannya, yaitu pembiayaan dengan prinsip jual beli, prinsip sewa, prinsip bagi hasil dan akad pelengkap. Pembiayaan dengan prinsip jual beli terdiri dari murabahah, salam, istishna'. Sedangkan pembiayaan dengan prinsip sewa, misalnya ijarah dan Ijarah Muntahiyah bit Tamlik (IMBT). Prinsip bagi hasil yakni mudharabah dan musyarakah. Untuk prinsip akad pelengkap misalnya, qardh, hiwalah, kafalah, dan wakalah.

Pada produk penyaluran dana, menurut data statistik perbankan syariah Juni 2011, pembiayaan pada Bank Umum Syariah (BUS) dan Unit Umum Syariah (UUS) yang dominan adalah pembiayaan dengan prinsip jual beli. Meskipun dari ketiga akad tersebut memiliki selisih yang jauh berbeda yaitu murabahah (46.161), istishna' (322) dan salam (0). Komposisi pembiayaan pada BUS dan UUS ini ditunjukkan pada tabel 1.2. 
Tabel 1. 2 Komposisi Pembiayaan pada Bank Umum Syariah dan Unit Usaha Syariah

\begin{tabular}{|l|c|}
\hline \multicolumn{1}{|c|}{ Akad } & Jumlah (dalam milyar rupiah) \\
\hline Mudharaba & 9.549 \\
\hline Musyarakah & 16.295 \\
\hline Murabahah & $\mathbf{4 6 . 1 6 1}$ \\
\hline Istishna & $\mathbf{3 2 2}$ \\
\hline Salam & $\mathbf{0}$ \\
\hline Ijarah & 2.297 \\
\hline Qardh & 7.362 \\
\hline Lainnya & 0 \\
\hline Total & $\mathbf{8 2 . 6 1 6}$ \\
\hline \multicolumn{2}{|c|}{ Sumber : Statistik Perbankan Syariah Indonesia - Vol 9 No. 9, Agustus 2011 } \\
\hline
\end{tabular}

Selisih penyaluran pembiayaan pada prinsip jual beli yang jauh berbeda tersebut dikarenakan adanya pertimbangan risiko maupun kendala yang terjadi dalam praktik. Jika dilihat dari pembiayaan istishna' (tabel 1.3), terlihat bahwa pada tahun 2011, angka pembiayaan tidak selalu menunjukkan kenaikan. Bahkan terjadi penurunan pada bulan Februari sampai dengan Maret sebesar Rp 22 miliar.

Tabel 1. 3 Pembiayaan Istishna’ Pada Bank Umum Syariah dan Unit Usaha Syariah

\begin{tabular}{|lc|lc|l|ll|}
\hline & Jan & Fcb & Mar & Apr & Mei & Jun \\
\hline Alkad Istishna' 351 & 360 & 328 & 315 & 317 & 322 \\
\hline
\end{tabular}

Naik turunnya perkembangan pembiayaan istishna' ini dapat dilihat dengan jelas pada grafik 1.2.

Grafik 1. 2 Perkembangan pembiayaan Istishna' Pada Bank Umum Syari' ah dan Unit Usaha Syari'ah Tahun 2011

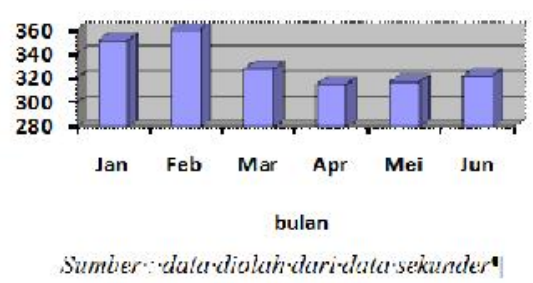

Menurut PSAK 104, menyebutkan tentang pengertian akad istishna' bahwa, 
Istishna' merupakan akad jual beli dalam bentuk pemesanan pembuatan barang tertentu dengan kriteria dan persyaratan tertentu yang disepakati antara pemesan (pembeli, mustashni') dan penjual (pembuat, shani').

Perbedaan dengan akad salam adalah dari segi barang. Pada akad salam diharuskan berupa barang pertanian. Sedangkan pada akad istishna', diharuskan berupa barang pesanan yang melalui proses konstruksi.

Pada akad istishna', terdapat dua tempo, yakni masa kontruksi dan pasca konstruksi. Sedangkan dari segi pengakuan pendapatan, menurut PSAK 104, yaitu;

Pendapatan istishna' diakui dengan menggunakan metode persentase penyelesaian atau metode akad selesai. Akad adalah selesai jika proses pembuatan barang pesanan selesai dan diserahkan kepada pembeli.

Selanjutnya, dijelaskan dalam PSAK 104 bahwa ada dua jenis pembayaran dalam akad istihna', yakni pembayaran tunai dan tangguh. Disebut sebagai pembayaran tunai jika, ketika barang selesai kemudian proses penyerahan, pelunasan pembayaran telah selesai. Sebaliknya, jika barang telah selesai dan diserahkan kepada pemesan tetapi angsuran belum selesai dan masih berlanjut, maka pembayaran ini dinamakan pembayaran tangguh.

Dalam praktek bank syariah, akad istishna' diwujudkan dalam berbagai produk. Salah satunya adalah Produk Apartemen. Produk ini merupakan produk pembiayaan di Bank Syariah X yang memakai akad istishna'. Melihat data bahwa selisih pembiayaan pada prinsip jual beli yang cukup jauh, maka kemungkinan muncul risiko maupun kendala pada praktik perbankan syariah. Kendala ini bisa dilihat dari relevan atau tidaknya penerapan PSAK 104 akuntansi istishna' jika dipraktikan secara penuh pada perbankan syariah. Dan kenyataannya, secara praktek pada Bank Syariah X tidak menerapkan PSAK 104 secara keseluruhan.

Bank sebagai pihak intermediasi antara pihak surplus dengan pihak defisit dituntut harus mampu untuk mengelola dana dari deposan kemudian disalurkan kepada nasabah sebagai debitur. Di sini, pihak bank berperan sebagai perantara dari kedua belah pihak, yakni sebagai penyimpan dana maupun sebagai kreditur. Dari kendala maupun risiko yang muncul, bank harus tetap mampu menerapkan prinsip umum akuntansi syariah, yaitu tanggung jawab, keadilan dan kebenaran. Ketiga unsur ini sangat berhubungan dengan penyaluran bagi hasil bagi nasabah. Dimana, setiap transaksi yang mempengaruhi pendapatan, harus diproporsikan sesuai dengan hak masing-masing nasabah.

Berkaitan dengan distribusi bagi hasil tersebut dan untuk meminimalisasi kerugian atas akibat sikap nasabah, maka secara praktek, Bank Syariah X menerapkan perlakuan akuntansi yang berbeda dengan PSAK 104. Hal inilah yang melatarbelakangi penulis mengambil judul "Evaluasi Perekayasaan Pencatatan Akuntansi Istishna' Ditinjau Dari Distribusi Bagi Hasil dan Legalitas Kepemilikan Pada Produk Apartemen Studi Kasus: Bank Syariah X". 


\section{TELAAH LITERATUR}

\subsection{ISTISHNA'}

Menurut PSAK 104, istishna' adalah akad jual beli dalam bentuk pemesanan pembuatan barang tertentu dengan kriteria dan persyaratan tertentu yang disepakati antara pemesan (pembeli, mustashni) dan penjual (pembuat, shani').

Gambar 2.1. Skema Istishna'

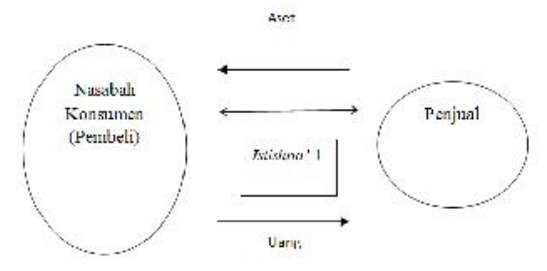

Sumber: Rizal \& Martawireja, (2009)

Dalam sebuah kontrak bai' al istishna', bisa saja pembeli mengizinkan pembuat menggunakan subkontraktor untuk melaksanakan kontrak tersebut. Dengan demikian, pembuat dapat membuat kontrak istishna' kedua untuk memenuhi kewajibannya pada kontrak pertama. Kontrak baru ini dikenal sebagai istishna' paralel. Istishna' paralel adalah suatu bentuk akad istishna' antara pemesan (pembeli, mustashni) dengan penjual (pembuat, shani'), kemudian untuk memenuhi kewajibannya kepada mustashni', penjual memerlukan pihak lain sebagai shani (AAOIFI, 315)

Gambar 2.2. Skema Istishna' Paralel

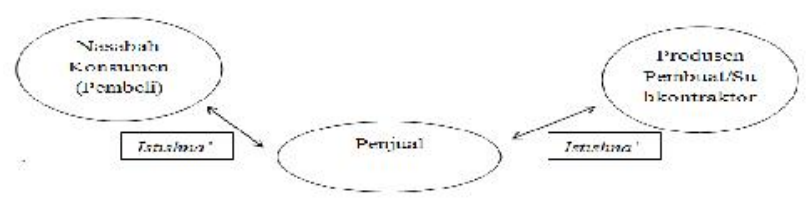

Sumber:Rizal \& Martawireja, (2009)

Menurut PSAK 104, nilai tunai adalah jumlah yang harus dibayar apabila transaksi dilakukan secara kas. Nilai wajar adalah jumlah yang dipakai untuk mempertukarkan suatu aset antara pihak-pihak yang berkeinginan dan memiliki pengetahuan memadai dalam suatu transaksi dengan wajar. Sedangkan pembayaran tangguh adalah pembayaran yang dilakukan tidak pada saat barang diserahkan kepada pembeli tetapi pembayaran dilakukan dalam bentuk angsuran atau sekaligus pada waktu tertentu.

Dalam skripsi ini, pembahasan yang akan diambil adalah terkait praktek istishna' dengan skema istishna' paralel. Bentuk pembayaran yang digunakan adalah pembayaran tangguh. Pola ini adalah pola yang umum ada pada perbankan syariah. 


\subsection{PRAKTEK ISTISHNA’ PADA BANK SYARIAH}

Ada beberapa konsekuensi saat bank Islam menggunakan kontrak istishna' paralel. Menurut Antonio (2001), konsekuensi tersebut antara lain:

a. Bank Islam sebagai pembuat pada kontrak pertama tetap merupakan satusatunya pihak yang bertanggung jawab terhadap pelaksanaan kewajibannya. Istishna' paralel atau subkontrak untuk sementara harus dianggap tidak ada. Dengan demikian, sebagai shani' pada kontrak pertama, bank tetap bertanggung jawab atas setiap kesalahan, kelalaian,atau pelanggaran kontrak yang berasal dari kontrak paralel.

b. Penerima subkontrak pembuatan pada istishna' paralel bertanggung jawab terhadap bank Islam sebagai pemesan. Dia tidak mempunyai hubungan hukum secara langsung dengan nasabah pada kontrak pertama akad. Istishna' kedua merupakan kontrak paralel, tetapi bukan merupakan bagian atau syarat untuk kontrak pertama. Dengan demikian, kedua kontrak tersebut tidak mempunyai kaitan hukum sama sekali.

c. Bank sebagai shani' atau pihak yang siap untuk membuat atau mengadakan barang, bertanggung jawab kepada nasabah atas kesalahan pelaksanaan subkontraktor dan jaminan yang darinya. Kewajiban inilah yang membenarkan keabsahan istishna' paralel, juga menjadi dasar bahwa bank boleh memungut keuntungan kalau ada.

Pada prakteknya, ketika bank menggunakan akad istishna' paralel maka bank melakukan kerja sama dengan pengembang karena bank bukan sebagai produsen barang. Kerja sama kedua adalah dengan pihak nasabah sebagai pemesan. Masing-masing kerjasama tersebut memiliki risiko. Oleh karena itu, bank syariah memiliki prosedur standar pelaksanaan yang dapat meminimalkan risiko yang muncul.

\subsection{PRAKTIK PEMBIAYAAN ISTISHNA' DAN ISTISHNA' PARALEL}

Anshori (2008) menjelaskan bahwa ketentuan teknis mengenai pembiayaan istishna' terdapat dalam fatwa DSN-MUI No. 06/DSN-MUI/IV/2000 tentang jual beli istishna'. Pengaturan mengenai pembiayaan istishna' dalam fatwa ini dibagi menjadi tiga bagian yaitu mengenai ketentuan tentang pembayaran, ketentuan tentang barang, dan ketentuan lain.

Sedangkan secara praktis, menurut Ascarya (2007), pelaksanaan kegiatan istishna' dalam perbankan syariah cenderung dilakukan dalam format istishna' paralel. Hal ini dapat dipahami karena:

1. Kegiatan istishna' oleh bank syariah merupakan akibat dari adanya permintaan barang tertentu oleh nasabah, dan

2. Bank syariah bukanlah produsen dari barang dimaksud.

Secara umum, tahapan praktik istishna' (dan istishna' paralel) di perbankan syariah adalah sama dengan tahapan praktik salam. Perbedaannya terletak pada cara pembayaran yang tidak dilakukan secara sekaligus, tetapi dilakukan secara bertahap (angsuran).

Sedangkan perbedaan antara praktik pada bank konvensional dengan bank syariah, yaitu terletak pada hubungan langsung antara pihak bank syariah 
dengan pengembang. Selain itu pada tahapan pencairan dana, yang langsung dilakukan oleh bank syariah sehingga dapat menghindari adanya mark up yang dilakukan oleh nasabah. Berdasarkan kompilasi SOP yang disampaikan oleh Bank Syariah, tahapan pelaksanaan istishna' dan istishna' paralel adalah seperti pada tabel berikut.

Tabel 2.1. Tahapan Pelaksanaan Istishna' dan Istishna' Paralel

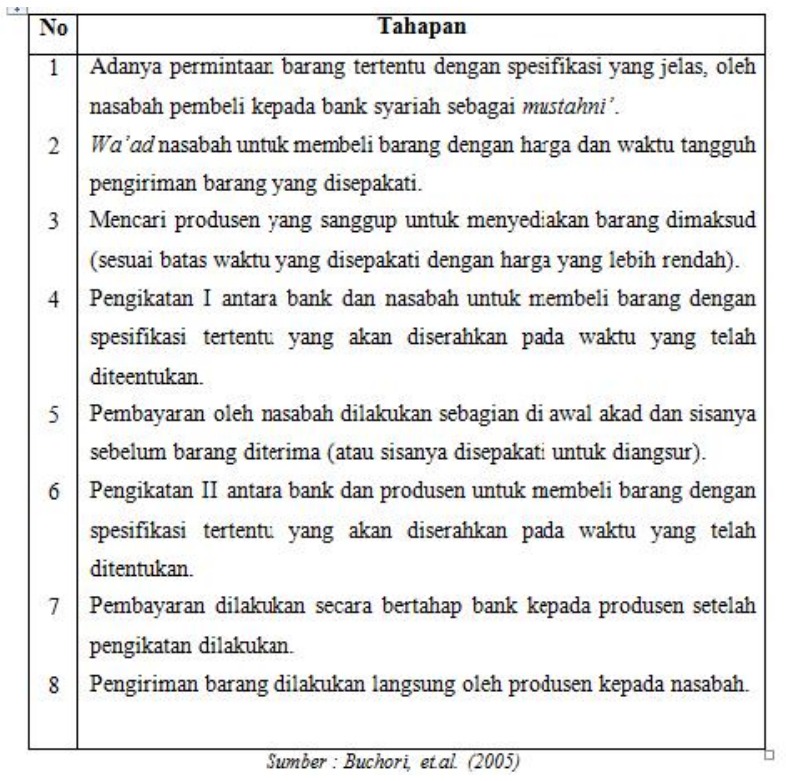

Dari hasil telaah atas SOP produk istishna', terdapat beberapa hal yang dapat dicermati lebih jauh, yaitu:

1. Secara umum pemahaman bank syariah terhadap akad istishna' adalah berkaitan dengan pembelian suatu benda yang memiliki nilai besar dan diproduksi secara bertahap, misalnya, bangunan, pesawat terbang, dan sebagainya.

2. Sama halnya dengan praktik salam, praktik akad istishna' di bank syariah hampir selalu dilakukan dalam format istishna' paralel. Dengan demikian praktik istishna' di perbankan syariah lebih terorientasi pada upaya pencarian margin antara harga akad I dan harga akad II.

Sama halnya dengan praktik salam, praktik istishna' di industri perbankan syariah lebih mencerminkan kegiatan utang piutang (penyediaan dana) daripada kegiatan jual beli. Implikasinya adalah pengakuan piutang istishna' lebih mencerminkan piutang uang (sebagai akibat kegiatan penyediaan dana) daripada piutang barang (sebagai akibat jual beli).

\subsection{PRODUK APARTEMEN}

Produk Apartemen adalah fasilitas pembiayaan pemilikan apartemen yang diberikan bank kepada nasabah untuk membeli apartemen dari bank, yang 
dibangun oleh pengembang berdasarkan pesanan nasabah dengan kondisi apartemen belum terbangun atau sedang dalam tahap pembangunan dengan menggunakan akad istishna. Produk ini kemudian disebut dengan Produk Apartemen.

Produk Apartemen merupakan produk pembiayaan dengan akad istishna'. Inovasi ini dilatarbelakangi oleh kepentingan bank syariah dalam peningkatan daya saing dalam dunia perbankan, optimalisasi pendapatan bank, dan sebagai bentuk pelayanan bank terhadap masyarakat tanpa mengabaikan penerapan prinsip syariah dan kehati-hatian. Fungsi produk pembiayaan apartemen ini adalah untuk memenuhi kebutuhan masyarakat akan perumahan yang sehat hunian di wilayah perkotaan. Bentuk pembiayaan ini yakni melalui proses pemesana terlebih dahulu.

Gambar 2.3. Skema Penandatanganan PPJB dan Persetujuan Pemberian Bank

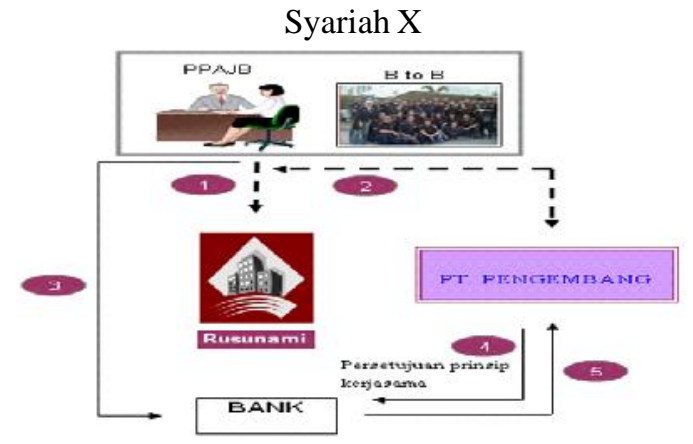

Tahap 1:

1. Pemesanan apartemen/sarusun dilakukan secara berkelompok dengan pendekatan B to B (Business to Business), melalui Kopkar ataupun developer.

2. Pemesanan apartemen/sarusun oleh kelompok karyawan/Kopkar ditindaklanjuti oleh developer dengan ditandatangani PPJB (Perjanjian Pengikatan Jual Beli atas bangunan apartemen/sarusun) kepada masingmasing calon nasabah (end user).

3. Selanjutnya kelompok keryawan melalui Kopkar mengajukan pembiayaan kepada bank guna mendapatkan pembiayaan PPA apartemen/sarusun secara angsuran/cicilan.

4. Dengan adanya pemesanan apartemen/sarusun secara berkelompok melalui mekanisme pembiayaan perbankan, selanjutnya developer mengajukan permohonan kerjasama kepada bank.

5. Bank memberikan jawaban persetujuan atau penolakan kepada developer. Jika bank memberikan persetujuan, maka bank akan memberikan persetujuan berupa persetujuan prinsip kepada developer yang ditetapkan dalam sebuah perjanjian kerjasama yang menyatakan bahwa selama memenuhi syarat dan ketentuan di bank, bank bersedia memberikan fasilitas pembiayaan PPR apartemen/sarusun kepada para karyawan (melalui perusahaan atau Kopkar) 
yang telah menjalin kerjasama dengan developer.

Gambar 2.4. Skema Pemberian Jaminan Buyback Guarantee oleh Developer

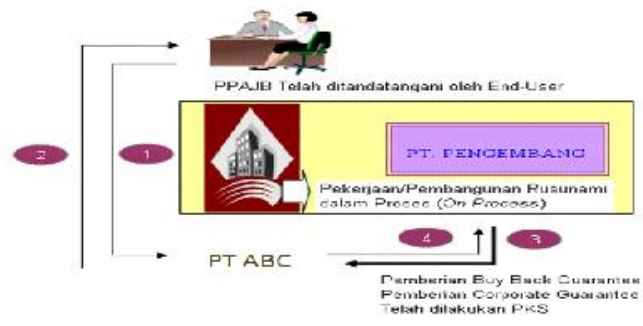

Tahap 2:

1. Nasabah (end user) mengajukan fasilitas jual beli barang atas pesanan barang (apartemen/sarusun) dengan spesifikasi dan syarat tertentu kepada bank, dengan konsep istishna'.

2. Bank memberikan persetujuan pencairan fasilitas jual beli atas pesanan barang dengan konsep istishna' dengan objek apartemen/sarusun kepada nasabah (end user).

3. Pada saat dilakukan pengikatan pembiayaan antara bank dengan nasabah "belum" didukung dengan pengikatan jaminan (karena objek jaminan dalam proses pembangunan belum dilakukan BAST dari pengambang), maka developer/pengembang mutlak memberikan jaminan berupa buy back guarantee (jaminan untuk membeli kembali) atas objek yang dipesan dengan dilampiri PKS yang telah ditandatangani antara bank dengan pengembang.

4. Drown down pencairan bertahap ke rekening developer/pengembang disesuaikan dengan komitmen \& progress yang telah diperjanjikan dan disepakati di awal.

Gambar 2.5. Skema Pelaksanaan RAST dari Develnner kenada Nasabah

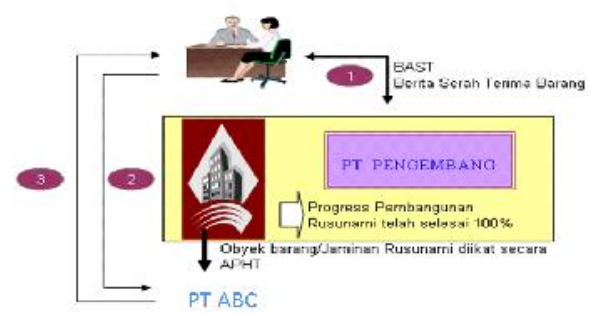

Tahap 3:

1. Nasabah (end user) terlebih dahulu telah menandatangani Berita Acara Serah Terima (BAST) berang berupa bangunan hunian apartemen/sarusun dari pengembang. Dengan telah ditandatangani BAST oleh nasabah (end user) artinya nasabah telah menerima secara sah dan utuh hunian apartemen sarusun.

2. Objek barang (apartemn/sarusun) sebanyak objek jaminan akan diikat. 


\section{METODEPENELITIAN}

Metode penelitian ini memakai metode deskriptif kualitatif dengan penelitian lapangan. Yaitu memaparkan dan menggambarkan variabel perekayasaan akuntansi istishna' secara. Analisis dilakukan dengan membandingkan antara pencatatan atau pengakuan akuntansi istishna' secara teori yang mengacu dari PSAK 104 dengan pencatatan atau pengakuan yang terjadi di lapangan. Selain data sekunder dan bahan literatur, analisis juga menggunakan data primer yang diperoleh dari hasil wawancara dengan pihak Bank Syariah X

\section{HASILDAN ANALISIS}

\subsection{KENDALA BANK SYARIAH DALAM PENERAPAN PSAK 104}

Perkembangan perbankan syariah secara positif berkembang dengan signifikan. Namun, dalam prakteknya, perbankan syariah masih mengalami kendala. Berdasarkan hasil wawancara, kendala pada perbankan syariah selaras dengan yang dipaparkan oleh Amin (2007), terkait pemahaman masyarakat, peraturan, sumber daya manusia, dan jaringan kantor. Dan ternyata, terdapat satu kendala lagi yang tergolong kendala internal, yaitu belum ada sistem teknologi yang mengakomodasi karakteristik usaha bank syariah. Poin kelima ini, merupakan poin tambahan kendala yang dihadapi pada bank syariah. Banyaknya variasi dalam pembiayaan pada bank syariah menimbulkan risiko operasional yaitu kesiapan sistem dan operasional yang mendukung kegiatan bank syariah tersebut. Pembiayaan yang bervariasi tersebut menyulitkan staf bagian Information Technology (IT) untuk membangun sistem yang mampu mengakomodasi semua varian pembiayaan tersebut yang sudah pasti tidak dapat ditemukan di pasar konvensional.

Berdasarkan kongres IAI (2010), industri perbankan syariah menghadapi kendala dalam menerapkan PSAK syariah karena PSAK syariah tidak selaras dengan praktek perbankan syariah. Hal ini terkait dengan poin kedua kendala yang disampaikan oleh Amin yaitu peraturan perbankan yang berlaku belum sepenuhnya mengakomodasi operasional bank syariah. Artinya, meskipun PSAK Syariah telah mengatur secara jelas, namun dalam penerapannya di lapangan peraturan tersebut belum sepenuhnya bisa diterapkan secara penuh.

Praktik yang belum dilaksanakan secara penuh ini disebabkan ketidakselarasan antara teori dengan praktik. Ketidakselarasan tersebut terjadi karena ada perbedaan sudut pandang antara PSAK syariah yang ditujukan untuk entitas yang melakukan transaksi riil, dengan industri perbankan syariah sebagai lembaga keuangan. Salah satu praktek pada perbankan syariah yaitu penerapan pada akad istishna'. Kendala yang dihadapi dalam aplikasi akad ini adalah dalam hal pengakuan keuntungan.

Menurut PSAK 104 paragraf 20 dan 22: istishna' dengan pembayaran tangguh dibagi sebagai berikut:

1. Pengakuan pendapatan pada masa konstruksi. 
a. Metode persentase penyelesaian.

b.Metode akad selesai.

2. Pengakuan pendapatan pada masa setelah penyerahan aset istishna' diakui secara proporsional sesuai PSAK 102: Akuntansi Murabahah paragraf 2425.

Dua macam pola pengakuan pendapatan istishna' rumit dan memberatkan back office bank serta membutuhkan investasi yang tinggi untuk IT dan SDM. Metode persentase penyelesaian digunakan jika pengakuan pendapatan didasarkan pada prosentase yang telah selesai. Sedangkan pengakuan pendapatan pada metode akad selesai yaitu pengakuannya ketika barang pesanan telah selesai dan diserahkan kepada nasabah yang memesan.

Secara singkat, ada tiga poin kendala yang dihadapi oleh bank syariah dalam praktiknya. Kendala tersebut diantaranya:

1. Investasi teknologi informasi (IT);

Dalam prakteknya, perbankan syariah membutuhkan sistem yang lebih rumit dibandingkan perbankan secara umumnya. Beragamnya akad yang ada sejalan dengan dibutuhkannya sistem yang lebih kompleks. Dalam hal ini misalnya pada akad istishna'. Seperti yang disebutkan di PSAK terkait dua tahapan dalam pembayaran tangguh yaitu pengakuan pendapatan ketika masa konstruksi dan pengakuan pendapatan setelah penyerahan aset.

Kedua tahapan pembayaran ini cukup rumit dalam pelaksanaannya. Salah satu kerumitan ini muncul ketika peralihan masa konstruksi ke masa setelah penyerahan aset pesanan nasabah. Peralihan masa ini membutuhkan sistem otomasi khusus agar lebih efektif dan efisien. Namun, dikarenakan belum bisa terpenuhinya kebutuhan ini, maka sistem yang masih digunakan adalah sistem manual. Hal ini bisa memunculkan kendala baru yaitu terkait ketelitian dan ketersediaan SDM.

2. Investasi sumber daya manusia (SDM).

Kendala SDM ini muncul sejalan dengan munculnya kendala kebutuhan IT. Informasi teknologi yang sudah bagus akan memunculkan risiko kebutuhan SDM yang kompeten dalam menjalankan sistem tersebut. Namun, ketika kebutuhan sistem otomasi tersebut belum terpenuhi, maka kebutuhan SDM yang lebih kompeten akan lebih tinggi. Penggunaan sistem manual akan membutuhkan SDM yang bukan hanya handal dalam hal komputerisasi tetapi juga dalam hal perbankan maupun akuntansi syariah. Karena sistem manual bukan merupakan sistem yang secara otomatis bekerja tanpa perhitungan lagi dalam input data. Jika SDM yang berlaku di dalamnya tidak kompeten khususnya tidak memiliki kompetensi di bidang tersebut, maka risiko kesalahan akan lebih banyak muncul.

Kendala terkait kedala tidak hanya sebatas komputerisasi. Kompetensi akuntansi syariah dan manajemen juga harus terpenuhi. Dengan melihat kondisi di praktek, baik dalam hal informasi teknologi maupun SDM, maka manajemen harus memiliki pemahaman yang cukup untuk megeluarkan kebijakan terkait implementasi PSAK. Kebijakan ini haruslah kebijakan yang mengakomodasi 
kedua tujuan. Yaitu menjaga kestabilan bank dengan tetap menjaga nilai-nilai syariah.

3. Kelaziman bisnis konstruksi apartemen di Indonesia.

Sebagian besar pengembang di Indonesia melaksanakan bisnisnya tidak berdasarkan pada PSAK 104. Pada prakteknya, pada metode prosentase penyelesaian, pengembang menjalankan kerjasamanya dengan pencairan dana terlebih dahulu.

Kendala tersebut merupakan poin yang menjadi kendala Bank Syariah X dalam menerapkan PSAK 104 secara penuh. Oleh karena itu, Bank Syariah X melakukan perekayasaan pada akad pencatatan akuntansi istishna' untuk mengatasi kendala - kendala tersebut sehingga tujuan bank tetap terakomodasi.

\subsection{PEREKAYASAAN AKUNTANSI ISTISHNA' PADA PRODUK APARTEMEN}

Setelah dibandingkan antara PSAK 104 dengan praktek di lapangan, ada tiga perbedaan yang menjadi fokus utama, yaitu terkait pencairan dana dari bank kepada pengembang, pencatatan untuk kebutuhan distribusi bagi hasil dan terkait pengakuan margin pada angsuran nasabah ketika masa konstruksi.

\section{Tahapan Pencairan Dana}

Pada PSAK 104, telah dijelaskan bahwa penentuan tahapan penyelesaian pada metode presentase penyelesaian untuk kepentingan pencairan dana dari pemesan kepada pengembang adalah dengan melihat pembangunan secara fisik yang telah dilakukan oleh pengembang. Prosentase pembangunan tersebut disepakati di awal ketika melakukan akad.

Namun, dalam prakteknya, Bank Syariah X melakukan pencairan dana sesuai dengan akad awal yang disepakati. Akad dalam pencairan dana tersebut bukan didasarkan pada seberapa besar tingkat penyelesaian, tetapi didasarkan pada dokumen tahapan yang bersangkutan. Secara teknis, pencairan dana sesuai nominal tersebut dilakukan ketika tiap tahapan telah tersedia dokumen yang bersangkutan.

Kesepakatan akad yang didasarkan pada ketersediaan dokumen ini dilakukan oleh Bank Syariah X karena pada industri bisnis konstruksi lazimnya menerima pencairan uang terlebih dahulu, baru terjadi pembangunan. Hal ini dikarenakan pengembang tidak ingin menanggung risiko yang tinggi. Dari kondisi tersebut, maka jika penerapan pencairan dilakukan sesuai tingkat penyelesaian seperti dalam PSAK 104, maka hal ini menjadi kendala bagi Bank Syariah X dalam memperoleh rekan kerja. Karena perekayasaan ini tidak memepengaruhi distribusi bagi hasil dan legalitas kepemilikan, maka hal ini tidak masalah selama adanya konsistensi dalam akad.

\section{Pengakuan Pendapatan Secara Akrual dan Cash Basis}

Pendapatan operasi utama merupakan pendapatan bank yang nantinya akan didistribusikan kepada pemilik dana. Jumlah dana yang akan didistribusikan kepada pihak ketiga ini merupakan pendapatan yang sudah diterima secara nyata. Hal ini digambarkan pada gambar 6. . 
Gambar 4.1. Skema Pendapatan dan Beban

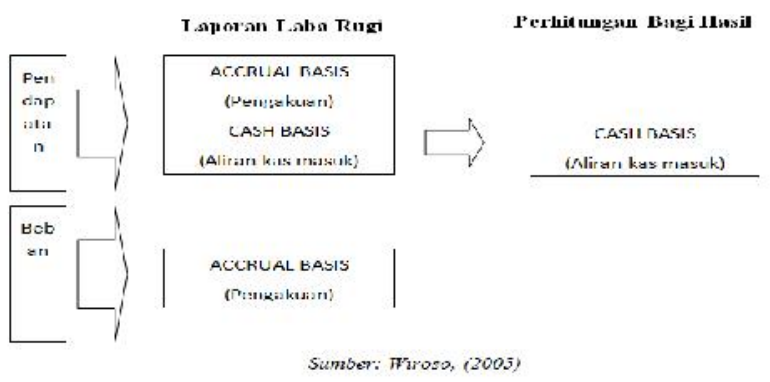

Perhitungan besar bagi hasil yang akan didistribusikan kepada pemilik dana yaitu dari pendapatan yang memang sudah diterima. Pendapatan yang masih dalam pengakuan belum bisa menjadi bagian pendapatan yang akan dibagikan kepada pemilik dana.

Dalam pembiayaan istishna' dengan pengakuan metode prosentase penyelesaian, pendapatan bersih istishna' diakui ketika besarnya prosentase penyelesaian yang telah dicapai berdasarkan akad dan berita acara kemajuan pembangunan. Pendapatan bersih istishna' tersebut diakui sebesar selisih antara pendapatan istishna' dan harga pokok istishna'.

Pembiayaan istishna' merupakan salah satu pembiayaan yang menggunakan dana pihak ketiga. Maka pendapatan yang nantinya dihasilkan dari pembiayaan ini merupakan pendapatan yang harus disalurkan kepada pemilik dana.

Pendapatan istishna' merupakan salah satu pendapatan operasi utama bank. Pada masa konstruksi, nasabah sudah mulai melakukan pembayaran angsuran. Dalam pembayaran angsuran, pendapatan bank belum merupakan pendapatan yang diterima oleh nasabah.

\begin{tabular}{|c|c|c|c|}
\hline \multicolumn{2}{|l|}{ PSAK 104} & \multicolumn{2}{|l|}{ Praktek } \\
\hline Db. Harga Pokok Istishna' & $\mathrm{xx}$ & Db. Harga Pokok Istishna' & $\mathrm{xx}$ \\
\hline Db. Aset Istishna' Dalam Penyelesaian & $\mathrm{xx}$ & Db. Aset Istishna' Dalam Penyelesaian & $\mathrm{xx}$ \\
\hline Kr. Pendapatan Istishna & $\mathrm{xx}$ & Kr. Pendapatan Istishna' Akru & $\mathrm{xx}$ \\
\hline
\end{tabular}

Pencatatan berdasarkan PSAK 104 dan secara praktek di atas memperlihatkan bahwa perbedaan yang terjadi adalah terkait penambahan kata 'akru'. Dari hasil wawancara, penambahan kata tersebut bertujuan untuk memudahkan sistem untuk membaca pendapatan istishna' yang sudah menjadi pendapatan kas dan pendapatan yang masih akrual.

Pengakuan pendapatan istishna' dengan menambahkan 'akru' tersebut difungsikan sebagai penjelas bahwa pendapatan istishna' tersebut masih dalam kategori pengakuan, belum termasuk penerimaan yang sudah diterima. Artinya, pendapatan ini belum menjadi bagian pendapatan yang akan didistribusikan kepada nasabah pemilik dana. 


\begin{tabular}{|c|c|c|c|}
\hline \multicolumn{2}{|l|}{ PSAK 104} & \multicolumn{2}{|l|}{ Praktek } \\
\hline Db. Rekening Nasabah & $\mathrm{xx}$ & Db. Rekening Nasabah & $\mathrm{xx}$ \\
\hline Kr. Piutang Istishna' & $\mathrm{xX}$ & Kr. Piutang Istishna' & $\mathrm{xx}$ \\
\hline & & Db. Pendapatan Istishna' Akru & $\mathrm{xx}$ \\
\hline & & Kr. Pendapatan Istishna' Kas & $\mathrm{xx}$ \\
\hline
\end{tabular}

Pada pencatatan di atas terlihat bahwa ketika pendapatan istishna' telah diterima, maka pendapatan tersebut diakui sebagai pendapatan yang telah diterima kas. Oleh karena itu bank menambahkan kata 'kas' pada jurnal tersebut.

Dalam sistem penjualan kredit dengan pembayaran secara angsuran, pendapatan atau keuntungan belum dapat diakui sebagai keuntungan bank sepenuhnya. Cicilan yang dibayarkan oleh nasabah kepada bank merupakan jumlah penerimaan yang diakui oleh bank sebagai penerimaan yang telah diterima. Besarnya pendapatan bersih dari cicilan tersebut sesuai dengan kebijakan akuntansi atau kesepakatan nasabah.

Dari ilustrasi jurnal di atas, ketika nasabah membayar sejumlah uang angsuran atas kewajiban dari pembiayaan istishna', maka angsuran tersebut akan mengurangi piutang istishna' bank. Pendapatan istisna' yang telah diterima kemudian diakui sebagai pendapatan istishna' kas, yang secara otomatis akan mengurangi pendapatan istishna' akru. Pendapatan istishna' kas ini akan menjadi bagian dari pendapatan bank yang akan didistribusikan kepada pemilik dana.

Adanya kejelasan proporsi pendapatan istishna' akru maupun kas ini, akan mempermudah bank dalam melakukan distribusi pendapatan. Hal ini dikarenakan kepentingan efisiensi, maka bank menggunakan sistem. Jika ada klasifikasi jurnal tersebut, maka sistem akan melakukan distribusi bagi hasil yang sesuai, yaitu pendapatan yang memang telah diterima oleh bank. Sehingga risiko kesalahan dalam perhitungan bagi hasil yang harus didistribusikan kepada pemilik dana akan lebih sedikit.

Hal ini sesuai dengan Kerangka Dasar Penyusunan Laporan Keuangan Bank Syariah, paragraf 14 sampai dengan 16 dijelaskan asumsi dasar, khususnya terkait dengan pengakuan pendapatan. Dalam paragraf tersebut telah jelas bahwa pengakuan pendapatan dengan tujuan untuk distribusi bagi hasil adalah dengan menggunakan metode kas.

Dalam format laporan keuangan bank syariah, bahwa perbedaan antara bank konvensional dengan bank syariah adalah adanya pos khusus yaitu pendapatan operasi utama pada bank syariah. Pos pendapatan operasi utama ini berfungsi sebagai akun yang mengakui semua pendapatan bank yang diperoleh dari operasi utama bank. Operasi utama ini misalnya, bagi hasil dari pembiayaan mudharabah, murabahah maupun pembiayaan lainnya yang menggunakan dana pihak ketiga. Di dalam pos pendapatan operasi utama ini, terkandung pendapatan yang diterima secara nyata (cash basis) dan juga terkandung pendapatan yang masih dalam pengakuan (accrual basis) .

Hal ini akan terkait dengan pengakuan pendapatan istishna' . Dalam teori, pengakuan tangguh dilakukan ketika masa konstruksi telah selesai dan masuk ke dalam pembayaran tangguh. Jika pengakuan akru ini diganti dengan pengakuan tangguh, maka hal ini akan mempengaruhi pada posisi pos 
pendapatan. Karena, jika pendapatan diakui sebagai pendapatan tangguh, maka pos tersebut berada di neraca. Sedangkan jika memakai akru atau cash, maka pos pendapatan tetap ada di laporan laba rugi.

Adanya pos pendapatan akru dan cash ini hanya berkaitan terkait kendala perhitungan secara otomatis klasifikasi pendapatan yang telah diterima dan pendapatan yang masih hanya sebagai pengakuan. Dan hal ini pengakuan ini akan otomatis disatukan ketika penyajian pada annual report laba rugi.

Jika dilihat dari pelaporan keuangan, menurut PSAK, rekonsiliasi pendapatan dan bagi hasil merupakan salah satu laporan keuangan yang wajib dibuat. Pada prakteknya, bank tetap membuat laporan rekonsiliasi pendapatan dan bagi hasil. Jadi, tidak adanya penambahan kata tersebut tidak masalah. Karena laporan rekonsiliasi tersebut sudah merupakan aplikasi realisasi distribusi bagi hasil, dan dalam pembuatannya pun tetap harus ada perhitungan pendapatan yang harus dibagi hasilkan. Namun, setelah dievaluasi, penambahan kata akru dan cash bisa lebih membuat efektif dan efisiensi waktu. Sehingga, ketika membuat rekonsiliasi pendapatan dan bagi hasil, akan memudahkan dalam perhitungan.

\section{Pengakuan Margin Pada Pembayaran Angsuran Masa Konstruksi}

Pembayaran angsuran pada masa konstruksi adalah/ pembayaran cicilan yang dilakukan oleh nasabah ketika masa pembangunan apartemen belum selesai. Pada saat pembayaran angsuran pada masa itu, Bank Syariah X melakukan pencatatan sebagai berikut:

\begin{tabular}{|c|c|}
\hline PSAK 104 & Praktek \\
\hline Db. Rekening Nasabah & Db. Rekening Nasabah \\
\hline \multirow{3}{*}{\begin{tabular}{|l|} 
Kr. Piutang Istishna'
\end{tabular}} & Kr. Piutang Istishna' \\
\hline & Db. Pendapatan Istishna' Akru \\
\hline & Kr. Pendapatan Istishna' Kas \\
\hline
\end{tabular}

Dari jurnal tersebut dapat disimpulkan bahwa uang yang dibayarkan oleh nasabah diakui seluruhnya oleh Bank Syariah X sebagai pendapatan istishna'. Jadi, ketika pembayaran angsuran dilakukan pada masa konstruksi, tidak ada pengakuan proporsi pembayaran pokok atas uang pembayaran tersebut. Praktis memang pembayaran masa konstruksi yang dilakukan oleh nasabah merupakan pembayaran margin atas pesanan barang. Sedangkan ketika masa tangguh nanti, pembayaran angsuran diakui sebagai pembayaran pokok dan margin. Namun, margin ini merupakan margin atas pembayaran tangguh. Bukan lagi margin atas pesanan. Karena pembayaran margin atas pesanan telah lunas ketika masa kontruksi.

Tujuan dari pengakuan penuh ini adalah ketika nasabah melakukan pembatalan perjanjian pada masa konstruksi, maka nasabah tidak dapat menuntut hak milik atas apartemen sesuai dengan jumlah uang yang telah dibayarkan ketika melakukan angsuran. Sedangkan dari pihak bank bisa langsung mengalihkan pembiayaan apartemen tersebut kepada nasabah lain. Hal ini terkait dengan kepemilikan atas apartemen tersebut. 
Jika bank mengakui pembayaran angsuran masa konstruksi tersebut sebagai pembayaran margin, maka ketika nasabah telah melakukan pembayaran tetapi di tengah pembangunan nasabah membatalkan perjanjian, nasabah tidak memiliki kepemilikan atas apartemen tersebut. Padahal di sisi lain, nasabah telah menyerahkan pembayaran tersebut ketika masa konstruksi. Seharunya, ada hak kepemilikan atas uang yang telah dibayarkan tersebut. Di sini muncul gap antara praktek dengan peraturan.

Seperti yang dijelaskan oleh Ascarya (2007) bahwa bank syariah cenderung menggunakan format istishna' paralel. Hal ini dikarenakan kegiatan istishna' sebagai akibat dari permintaan pesanan dari nasabah. Sehingga barang yang dipesan oleh para nasabah bukanlah barang yang selalu sejenis dan sama spesifikasinya. Hal ini terkait pula posisi bank bukan merupakan produsen dari barang yang dimaksud oleh nasabah.

Berdasarkan kondisi tersebut, maka bank harus melakukan dua perjanjian kerja sama secara terpisah. Pertama, hubungan dengan nasabah terkait pinjammeminjam uang untuk pembangunan apartemen. Kedua, terkait kerja sama dengan subkontraktor/pengembang atas pembangunan apartemen yang dipesan oleh nasabah.

Seperti yang telah dijelaskan oleh Antonio, (2010), bahwa perjanjian antara nasabah dengan pengembang adalah terpisah. Dalam istishna' paralel, bank melakukan dua kali perjanjian yaitu dengan pengembang dan nasabah. Atas dasar tersebut, maka bank syariah memiliki risiko penuh tehadap nasabah. Karena antara nasabah dengan pengembang tidak ada kaitan hukum sama sekali. Bank syariah akan bertanggung jawab jika terjadi kesalahan dalam pembuatan apartemen. Selain terkait nasabah dengan pengembang, bank syariah juga memiliki tanggung jawab terhadap pemilik dana. Hal ini dikarenakan, dana yang digunakan untuk pembiayaan istishna' merupakan dana pihak ketiga yang mana nantinya akan kembali kepada pemilik. Selain itu, ada kewajiban bagi bank untuk memberikan distribusi bagi hasil kepada pemilik dana. Baik tidaknya pengelolaan dana, akan berpengaruh pula terhadap kepercayaan para deposan ataupun calon pemilik dana lain untuk menginvestasikan dananya pada bank syariah.

Gambar 4.2. Alur Resiko Antar Pihak Pada Pembiayaan Istishna'

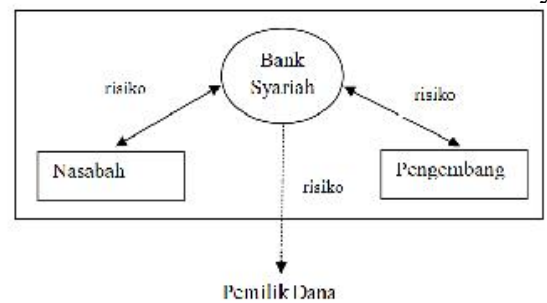

Sumber: Dafa diolah dari dala sekandkr/

Hal ini sejalan dengan pasal 2 UU No. 10 Tahun 1998, bahwa Perbankan Indonesia dalam melakukan usahanya berasaskan Demokrasi Ekonomi dengan menggunakan prinsip kehati-hatian. Prinsip kehati-hatian ini mengharuskan 
pihak bank untuk selalu berhati-hati dalam mengelola usahanya. Hal ini sejalan juga dengan pasal 29 ayat 2 disebutkan bahwa

Bank wajib memelihara tingkat kesehatan bank sesuai dengan ketentuan kecukupan modal, kualitas aset, kualitas manajemen, likuiditas, rentabilitas, solvabilitas, dan aspek lain yang berhubungan dengan usaha bank, dan wajib melakukan kegiatan usaha sesuai dengan prinsip kehati-hatian.

Prinsip kehati-hatian ini harus dilakukan oleh bank karena dana yang dikelola oleh bank syariah merupakan dana pihak ketiga, yang mana nantinya akan kembali ke pemilik dana.

Jika dievaluasi dari sisi syariah, maka hal ini terkait dengan akad di awal. Ketika pada saat akad nasabah menyetujui bahwa pembayaran angsuran pada masa konstruksi adalah pembayaran margin pemesanan, maka pengakuan margin secara penuh pada masa konstruksi ini tidak masalah, karena kedua belah pihak saling sepakat. Dalam akad istishna', ketika barang masih dalam tahap penyelesaian dan belum ada serah terima barang, maka hal ini belum mengikat (lazim) sehingga masih berlaku hukum khiyar (pilihan). Jadi, perubahan akad diperbolehkan ketika belum ada serah terima barang.

Terkait dengan pembatalan kontrak secara sepihak dari nasabah ketika masa konstruksi, hal ini harus kembali kepada akad yang telah disepakati. Karena pembayaran angsuran untuk pembayaran margin merupakan kesepakatan kedua belah pihak, maka secara hak, nasabah tidak memiliki kekuatan untuk meminta kembali uang yang telah dibayarkan kepada bank. Hal ini telah menjadi risiko bagi nasabah dikarenakan pembatalan di tengah akad. Jika dikaitkan dengan pembagian risiko, maka hal ini sebaiknya ada negosiasi dari kedua belah pihak jika itu dimungkinkan. Sehingga meskipun terjadi pembatalan, maka kedua belah pihak tidak ada yang dirugikan.

Namun, jika dievaluasi dari sisi hukum positif, maka pengakuan margin pada pembayaran angsuran masa konstruksi yang terjadi di lapangan memiliki dampak sebagai berikut:

1. Bagi Nasabah

Jika dilihat dari sisi syariah, maka praktek tersebut tidak sesuai dengan konsep syariah. Hal ini bisa dibandingkan dengan konsep urbun menurut fatwa No. 13, yakni adanya pengembalian uang muka murabahah yang telah dibayarkan nasabah jika jumlahnya lebih besar dibandingkan dengan jumlah kerugian akibat pembatalan pemesanan.

Jika dilihat dari sisi hukum positif, maka adanya pembatalan pemesanan mengakibatkan nasabah tidak memiliki hak kepemilikan atas apartemen atau tidak ada pengembalian angsuran yang telah dibayarkan, maka hal ini dapat merugikan pihak nasabah. Karena uang yang telah dibayarkan nasabah kepada bank merupakan pembayaran angsuran. Jika tidak ada pengembalian, maka hal ini tidak sesuai dengan hukum jual beli. Yakni terkait pengakuan margin. Margin muncul jika ada jual beli. Namun, ketika nasabah membatalkan jual beli ketika masa konstruksi, maka jual beli akan dibatalkan secara sepihak. Jika semua pembayaran yang telah dilakukan oleh nasabah menjadi pendapatan bagi bank 
sedangkan jual beli ada pembatalan, maka hak atas pembayaran tersebut belum menjadi pendapatan bank.

Namun, terkait perjanjian, nasabah memang melakukan pelanggaran perjanjian yang telah disepakati di awal. Terkait perjanjian, hal ini diatur dalam KUHPerdata. Pasal 1338 KUHPerdata menyatakan bahwa,

Semua perjanjian yang dibuat secara sah berlaku sebagai undangundang bagi mereka yang membuatnya. Semua perjanjian tidak dapat ditarik kembali selain dengan sepakat kedua belah pihak, atau karena alasan-alasan yang oleh undang-undang dinyatakan cukup untuk itu.

Dalam pasal 1338 tersebut dapat disimpulkan bahwa adanya prinsip pacta sunt servanda (perjanjian mengikat bagi para pihak pembuatnya). Pasal 1338 KUHPerdata mengandung beberapa asas-asas kontrak. Kata "semua" menunjukan bahwa setiap orang bebas untuk menyatakan keinginan yang diperlukan untuk membentuk perjanjian. Prinsip kebebasan berkontrak juga dapat ditemukan melalui kata "semua perjanjian...". Namun, kebebasan tersebut ada batasannya. Asas ini dibatasi dengan ketentuan dalam Pasal 1320 KUHPerdata yaitu isi dari kontrak tidak boleh melanggar peraturan perundang undangan yang berlaku, kepatutan dan ketertiban umum.

Semua perjanjian tidak dapat tiba-tiba ditarik kembali kecuali adanya kesepakatan dari kedua belah pihak yang melakukan kerja sama. Perjanjian merupakan undang-undang bagi pelakunya. Dalam transaksi pembiayaan syariah, nasabah dan bank terikat dengan kontrak dan peraturan perundangundangan yang berlaku. Misalnya, dalam hal perbankan, selain perjanjian yang berlaku, Peraturan Bank Indonesia juga menjadi peraturan yang mengikat subjek pelaku.

2. Pihak Bank

Jika dikaitkan dengan pasal 1338 KUHPerdata, bahwa kedua belah pihak dalam perjanjian haruslah memiliki kekuatan yang sama. Realitanya, ketika nasabah mengajukan pembiayaan kepada bank, maka pihak yang memiliki kekuatan adalah bank. Sehingga kemungkinan untuk menetapkan kesepakatan khususnya terkait klausal baku yang telah dibuat di awal akan diterima oleh nasabah karena posisi nasabah yang lemah, yang khawatir pengajuannya ditolak. Kondisi sebaliknya akan dirasakan oleh bank ketika masa pasca pencairan dana sampai pelunasan angsuran. Bank bisa menjadi posisi lemah karena terkait kelancaran pembayaran angsuran oleh nasabah.

Di dalam hukum perjanjian pada bank konvensional, ketika nasabah mengajukan pinjaman KPR, maka bank akan langsung mengatasnamakan nasabah sebagai pemilik perumahan tersebut. Sehingga jika nantinya gagal bayar, nasabah akan dapat mengalihkan pinjamannya tersebut ke bank lain (take over).

Sedangkan pada bank syariah, pembiayaan perumahan atau apartemen masih tetap kepemilikan bank, belum atas nama nasabah yang melakukan pembiayaan. Sehingga ketika nasabah tidak mampu membayar atau membatalkan perjanjian, maka bank syariah dapat mengalihkan pembiayaan tersebut kepada nasabah lainnya. 
Dari pasal 1338 tersebut bila dikaitkan dengan perjanjian akad syariah pada pembiayaan bank syariah, ketika nasabah melakukan pembatalan pembiayaan istishna' pada masa konstruksi tanpa alasan yang memaksa seperti pada pasal 1244 dan 1245 KUH Perdata, maka bank biasanya memberikan beberapa pilihan:

1. Nasabah harus tetap melunasi pembiayaan tersebut terkait hak milik apartemen yang semula dipesan.

2. Nasabah berhenti membayar tetapi uang yang telah dibayarkan tidak dapat dikembalikan lagi.

Artinya, ketika nasabah berhenti membayar, maka uang yang sudah dibayarkan kepada bank tidak dapat dikembalikan lagi.

3. Nasabah melakukan take over atau mengalihkan pembiayaan ke bank lain.

Dari penjelasan tersebut, maka dapat disimpulkan bahwa bank dapat memberikan kebijakan dalam kontrak karena terkait kehati-hatian bank dalam meminimalisasi kemungkinan kerugian yang terjadi. Sedangkan pihak nasabah, idealnya juga melakukan pertimbangan atas kesepakatan perjanjian supaya kedudukan kedua belah pihak seimbang. Dan kesepakatan ini tidak boleh melanggar perundang-undangan yang berlaku.

Poin kedua jika dihubungkan dengan UU RI No.8 Tahun 1999 tentang Perlindungan Konsumen, maka pernyataan tersebut bisa dikategorikan sebagai pelanggaran perlindungan konsumen yaitu pada pasal 18 terkait pelarangan adanya klausal baku oleh pemilik usaha. Pelarangan klausal baku ini disebutkan secara tegas dalam ayat 1c yang menyatakan bahwa pelaku usaha berhak melakukan penolakan kembali uang yang telah dibayarkan atau barang yang telah dibeli oleh konsumen.

Pembayaran angsuran sebagai pembayaran keuntungan, bisa didukung oleh pasal 1398. Yang berbunyi,

Jika seorang yang mempunyai berbagai utang uang, menerima suatu tanda pembayaran, dimana si berpiutang telah menyatakan bahwa apa yang diterimanya itu ialah khusus untuk melunasi salah satu diantara utang-utang tersebut, maka tak dapat lagi si berutang menuntut supaya pembayaran itu dianggap guna pelunasan suatu utang yang lain, kecuali jika dari pihaknya si berpiutang telah dilakukan penipuan atau si berutang dengan sengaja tidak diberi tahu tentang adanya pernyataan tersebut.

Dalam pasal tersebut berarti pihak yang berpiutang atas beberapa hutang memiliki hak untuk menentukan hutang mana yang dibayar oleh pihak yang berhutang selama hal itu disampaikan oleh pihak yang berpiutang. Secara sekilas, jika hal ini dikaitkan dengan angsuran nasabah pembiayaan istishna' pada masa konstruksi, maka pengakuan pembayaran tersebut sebagai pembayaran margin istishna' diperbolehkan selama nasabah telah mengetahui kebijakan tersebut ketika perjanjian dilaksanakan. Namun, jika dilihat dari jual beli yang mana muncul margin, maka hal ini bisa bisa dikatakan tidak sesuai. 
Jika dikaitkan dengan UU No. 8 Tahun 1999 Pasal 18 ayat 1, poin a bisa tergolong sebagai klausal baku yang dimaksud dalam ayat $1 \mathrm{c}$. Jika nantinya terjadi wanprestasi dari nasabah, uang angsuran tidak bisa dikembalikan dan tetap menjadi pendapatan keuntungan untuk bank. Namun, hal ini bisa menjadi kendala bagi bank jika nantinya terjadi tuntutan dari nasabah. Karena pendapatan yang telah diakui oleh bank tersebut telah masuk ke dalam proporsi bagi hasil yang akan dibagikan kepada pihak pemilik dana.

Jika didasarkan pada hukum, pasal 18 dan konsep bagi hasil, maka pengakuan secara penuh atas margin ini bisa berdampak negatif untuk bank. Hal ini dikarenakan, ketika pembayaran pada masa konstruksi tersebut diakui sebagai pendapatan istihna' kas, maka pendapatan ini telah masuk menjadi bagian pendapat yang harus dibagikan kepada pihak ketiga. Padahal, jika dikaitkan dengan pasal 18, hal ini bisa masuk dalam pelanggaran hukum.

Pelanggaran ini bisa menjadi kekuatan hukum bagi nasabah untuk mendapatkan hak kepemilikan atau hak pengembalian uang yang telah dibayarkan. Dampaknya, hal ini akan menjadi kerugian bagi bank. Bank harus mengembalikan uang pembayaran kepada nasabah, padahal pembayaran yang telah diakui sebagai pendapatan tersebut telah didistribusikan kepada pihak ketiga. Artinya, bank akan mengeluarkan dana yang lebih besar untuk ganti rugi kepada nasabah.

\section{SIMPULAN}

Perekayasaan pencatatan yang dilakukan oleh Bank Syariah X memiliki dasar dan dampak sebagai berikut:

a. Tahapan pencairan dana didasarkan pada dokumen merupakan jalan tengah yang diambil oleh bank syariah karena kendala sulitnya mendapatkan rekan pengembang jika pelaksanaan tahapan pencairan dana dilakukan sesuai dengan PSAK 104. Sementara perusahaan - perusahaan konstruksi menggunakan PSAK 34, sedangkan Bank Syariah X menggunakan PSAK 104. Karena hal ini tidak terkait dengan distribusi bagi hasil dan legalitas kepemilikan, maka hal ini masih bisa diterima.

b. Pengakuan pendapatan secara akru dan kas dapat memudahkan sistem untuk mengklasifikasikan pendapatan yang sudah diterima dan pendapatan yang masih dalam pengakuan. Dari hasil evaluasi, pencatatan ini bisa menjadi alternatif terkait kendala IT. Hal ini dapat meminimalkan kesalahan dalam distribusi bagi hasil kepada pemilik dana secara otomasi. Sehingga dapat menambah efektivitas dan efisiensi kinerja bank terkait penyusunan laporan rekonsiliasi pendapatan dan bagi hasil.

c. Pengakuan pendapatan margin pada pembayaran angsuran masa konstruksi jika dilihat dari hukum syariah dan hukum positif memiliki dampak sebagai berikut:

1. Segi syariah 
Dari segi syariah, pengakuan margin pada pembayraan angsuran masa konstruksi tidak masalah jika kedua belah pihak baik nasabah maupun bank telah sepakat pada saat akad. Terkait pembatalan akad pada masa konstruksi, maka tidak ada pengembalian uang yang telah dibayarkan merupakan risiko bagi nasabah. Namun, hal ini bisa dimungkinkan adanya negosiasi karena belum ada serah terima barang. Dalam sifat akad, ketika belum ada serah terima barang maka akad ini belum (lazim). Lazimnya akad terjadi ketika barang telah ada dan telah ada serah terima barang kepada pemesan. Jika akad masih belum lazim, maka perubahan akad masih bisa dilakukan. Oleh karena itu ketika terjadi pembatalan, negosiasi antara bank dan nasabah untuk mengambil jalan tengah masih bisa dilakukan.

2. Segi hukum positif

a. Dari sisi legalitas kepemilikan

Setelah dievaluasi, meskipun nasabah yang melakukan pelanggaran perjanjian karena pembatalan pesanan secara sepihak, namun jika dilihat dari sisi legalitas kepemilikan hal ini menimbulkan kerugian bagi nasabah. Pengakuan margin secara penuh tersebut dapat melanggar Pasal 18 ayat 1c UU No. 8 tahun 1999 tentang Perlindungan Konsumen karena tidak ada pengembalian ketika ada pembatalan perjanjian oleh nasabah.

b. Dari sisi distribusi bagi hasil

Dari dampak legalitas di atas, hal ini dapat menimbulkan kerugian bagi bank dari sisi distribusi bagi hasil. Nasabah memiliki kekuatan melakukan tuntutan kepada bank atas dana yang telah dibayarkan atau proporsi kepemilikan atas apartemen. Dalam posisi ini, pihak bank harus mengembalikan dana nasabah setelah dikurangi kerugian yang muncul akibat pembatalan pmesanan, sedangkan bank telah mendistribusikan angsuran tersebut kepada pemilik dana karena bank mengakui angsuran tersebut sebagai pendapatan margin istishna' yang telah diterima secara kas.

\section{DAFTAR PUSTAKA}

Amin, M. 2007. Prospek Cerah Perbankan Islam. Jakarta: LEKAS (Lembaga Kajian Agama dan Sosial).

Anshori, A. G. 2008. Kapita Selekta Perbankan Syari'ah di Indonesia. Yogyakarta: UII Press.

Antonio, M. S. 1999. Bank Syari'ah : Bagi Bankir dan Praktisi Keuangan. Jakarta: Bank Indonesia.

Antonio, M. S. 2001. Bank Syari'ah : Dari Teori ke Praktik. Jakarta: Gema Insani Press. 
Ascarya. 2007. Akad dan Produk Bank Syari'ah. Jakarta: PT Raja Grafindo persada.

BSM. 2010. "Hambatan dan Tantangan Penerapan PSAK Syariah Di Bank Syariah," materi yang disampaikan dalam Kongres XI Ikatan Akuntan Indonesia di Jakarta, 9 Desember 2010.

DSAK IAI. 2010. Pernyataan Standar Akuntansi Keuangan (PSAK) No. 109 Akuntansi Zakat dan Infak/Sedekah. Jakarta: IAI

IAI. 2009. Pernyataan Standar Akuntansi Keuangan. Jakarta: Graha Akuntan.

IAI. 2010. Seminar : Hambatan dan Tantangan Penerapan PSAK Syari'ah di Bank Syari'ah. Jakarta.

Ismail. 2010. Manajemen Perbankan : Dari Teori Menuju Praktik. Jakarta: Kencana.

Karim, A. A. 2010. Bank Islam Analisis Fiqih dan Keuangan. Jakarta: PT Raja Grafindo Persada.

Karim, Adiwarman. (2010). "Hambatan dan Tantangan Penerapan PSAK Syariah," materi yang disampaikan dalam Kongres XI Ikatan Akuntan Indonesia di Jakarta, 9 Desember 2010.

Martawireja, R. Y. 2009. Akuntansi Perbankan Syari'ah. Jakarta: Salemba Empat.

Mohammad, A. K. 1992. Hukum Perikatan. Bandung: Citra Aditya Bhakti.

Romansyah, Dadang. 2012. "Isu Terbaru tentang Perkembangan Akuntansi Syariah," materi yang disampaikan dalam PPL Free Anggota IAI dan Alumni Brevet IAI Ikatan Akuntan Indonesia Cabang Mall of Indonesia di Jakarta, 31 Mei 2012

Sugiyono. 2010. Metode Penelitian Bisnis. Bandung: Alfabeta.

Suwardjono. 2005. Teori Akuntansi Perekayasaan Pelaporan Keuangan. Yogyakarta: BPFE Yogyakarta.

Tim-Pengembangan, P. S. 2003. Konsep Produk dan Implementasi Operasional Bank Syari'ah. Jakarta: Djambatan.

Wasilah, N. d. 2008. Akuntansi Syari'ah di Indonesia. Jakarta : Salemba Empat.

Wibisana, M. Jusuf. 2010. "Tantangan atas Penerapan SAK Syariah," materi yang disampaikan dalam Kongres XI Ikatan Akuntan Indonesia di Jakarta, 
9 Desember 2010.

Wiroso. (2005). Penghimpunan Dana dan Distribusi Hasil Usaha Bank Syari'ah. Jakarta: PT Grasindo. 